\title{
Childhood hunger experiences and chronic health conditions later in life among Brazilian older adults
}

\author{
Lucía Félix-Beltrán ${ }^{1}$ and Brayan V. Seixas ${ }^{1}$
}

Suggested citation Félix-Beltrán L and Seixas BV. Childhood hunger experiences and chronic health conditions later in life among Brazilian older adults. Rev Panam Salud Publica. 2021;45:e39 https://doi.org/10.26633/RPSP.2021.39

ABSTRACT Objectives. To assess the association between childhood hunger experiences and the prevalence of chronic diseases later in life.

Methods. A cross-sectional study was conducted using baseline data from the Brazilian Longitudinal Study of Aging (ELSI-Brazil), a nationally representative study of persons aged 50 years and older $(n=9412)$. Univariate and bivariate analyses were used to describe the sample, and multivariate logistic regressions to examine the association between childhood hunger and hypertension, diabetes, arthritis and osteoporosis. Adjusted odds ratios and predicted probabilities were calculated.

Results. 24.7\% of Brazilians aged 50 and over experienced hunger during childhood. This harmful exposure was significantly more common among non-white people, individuals with lower educational attainment, lower household income and heavy manual laborers. Regional variation was also observed, as the prevalence of individuals reporting childhood hunger was higher in the North and Northeast regions. The multivariate analysis revealed that older adults who reported having experienced hunger during childhood had $20 \%$ higher odds of developing diabetes in adulthood (aOR $=1.20,95 \% \mathrm{Cl}: 1.02-1.41)$ and $38 \%$ higher odds of developing osteoporosis $(\mathrm{aOR}=1.38,95 \% \mathrm{Cl}: 1.15-1.64)$ than adults who did not experience hunger during childhood, after controlling for covariates.

Conclusions. The study showed an association between childhood hunger and two chronic diseases in later life: diabetes and osteoporosis. This work restates that investing in childhood conditions is a cost-effective way to have a healthy society and provides evidence on relationships that deserve further investigation to elucidate underlying mechanisms.

Keywords Hunger; chronic disease; aging; diabetes mellitus; osteoporosis; Brazil.

The fact that childhood environments can have long-lasting effects along the life course has made their study increasingly popular. Existing evidence supports that being exposed to multiple adverse experiences such as abuse, neglect and household dysfunction during childhood can result in a higher risk of adult obesity (1), heart disease (2), and decreased functional health $(3,4)$, among others. A recent review found that adverse childhood experiences were associated to a gamut of adult health conditions ranging from lower physical activity, overweight, diabetes, smoking, alcohol/drug use to self-directed violence
(5). However, these findings consider a wide set of experiences and their relationship to adult outcomes, while each type of adverse experience might have different causal pathways and results. For instance, not receiving nutrients during childhood results in direct epigenetic changes and 're-programming' of bodily functions causing metabolic disfunction which manifests in higher risk of diabetes, hypertension and cardiovascular diseases later in life (6). This pathway might involve an adverse childhood experience such as food deprivation but not household dysfunction. The need to understand the different

\footnotetext{
1 University of California at Los Angeles, Los Angeles, United States of America.

$\triangle$ Lucía Félix-Beltrán, luciafelix@ucla.edu
} 
mechanisms through which these experiences unfold, has set the stage for a growing body of evidence that takes a life-course approach focusing particularly on childhood hunger experiences and their consequences on the health of older adults.

Existing evidence from European countries shows that people exposed to hunger in childhood reported lower life satisfaction (7), depression (8), developed up to $40 \%$ more health deficits $(6,9)$, lower physical activity and had a higher likelihood to smoke (10) than individuals who did not experience hunger. Moreover, the association between childhood hunger and adult health remained significant even after considering the moderating role of socioeconomic position during early adulthood (9). Among Russian individuals, having reported hunger in childhood was associated to lower educational attainment and poor health (11). These associations are not consistent across countries. For instance, in Indonesia, hunger experiences were not significantly associated to adult cognition (12), but in China, a country with severe famine episodes, nutritional deficiencies during childhood were positively associated with cognitive impairment (13), functional limitations $(4,14)$ as well as overweight and depression (15). Among the causal mechanisms underlying these associations it is possible to identify physiological alterations in previously undernourished individuals' growth velocity, positive energy balance and fat accumulation (16), and changes in endocrine and immune systems (17).

In addition to the study of early hunger on metabolic dysfunction, there is an increasing number of studies that explores the link between childhood hunger and bone mass in old age (18). This came into the spotlight after World War II when famine and food restrictions led to dramatically low mean caloric intake among prisoners of concentration camps (19). This interest has extended to the current studies on famine exposure and hunger. For instance, a study in a Chinese province found that exposure to famine during early childhood had negative effects on bone quality and was associated with a higher risk of osteoporosis, particularly among postmenopausal women (20), and on functional limitations at the national level (14). One of the proposed underlying mechanisms is that bone mass accumulates with skeletal growth (21), which depends on calcium and vitamin D levels. Thus, a deficiency of vitamin $\mathrm{D}$ might result in a decreased bone mass and frailty later in life $(18,22)$, pointing out the long-term implications of nutritional deficiencies during childhood (23).

The long-term consequences of the historical burden of undernutrition in Brazil merit exploration. An existing review states the association between childhood stunting -a consequence of hunger- and an increased risk of obesity and chronic degenerative diseases in adulthood (24). In addition, results from a cohort study indicate that childhood nutritional stunting was associated with long-term impairment of fat oxidation, a factor closely associated to obesity (25). Most of the existing evidence on the long-term outcomes of childhood hunger experiences assesses these effects until adolescence or early adulthood. The few studies that do extend into older age found that hunger experiences during childhood were associated with higher odds of poor self-rated health, comorbidity, cognition, depression, and physical functionality (26), frailty -with a differential effect on women- (27), and inconclusive evidence on the moderating role of mobility on these outcomes $(26,28)$.

In this context, we seek to expand the understanding of health conditions with a life-course perspective and aim to answer: what is the association between childhood hunger experiences and chronic health conditions in late adulthood? To address this question, this study uses baseline data from the Brazilian Longitudinal Survey of Aging (ELSI-Brazil) to assess the association between having experienced hunger during childhood and hypertension, diabetes, heart disease, rheumatism and osteoporosis among adults older than 50 years of age.

\section{METHODS}

\section{Data and sample}

A cross-sectional study was conducted using data from the baseline evaluation of the Brazilian Longitudinal Survey of Aging (ELSI-Brazil). This is a household survey of Brazilians aged 50 and over collected with the objective of understanding the social and biological aspects involved in the aging process. Respondents were selected based on a multi-stage cluster sample, stratified by municipality, census tract and residence. Baseline data were collected between 2015 and 2016; subsequent waves are planned to occur every 3-4 years. A total of 9412 people, across 70 municipalities and all five major geographic regions in Brazil were part of the initial assessment, which included the collection of retrospective measures through; 1) household interviews; 2) individual interviews; 3) physical measurements; and 4) blood tests. A more detailed methodological description of ELSI-Brazil can be found elsewhere (29).

\section{Measures}

Our independent variable was assessed with the respondent's answer to the question: From your birth until you were 15 years old, have you ever had a lack of food in your home and ended up going to bed feeling hungry? This self-reported measure has been used in studies of similar nature $(12,13,26,27)$. Our dependent variables were coded as binary responses to the questions of whether or not respondents had been ever diagnosed with hypertension, diabetes, any heart disease, arthritis or rheumatism and/or osteoporosis. A series of demographic and health factors were included as independent variables, specifically sex, age group, race, education, household income (in terms of federal established monthly minimum wage), macrogeographic region, whether or not the person lives with a partner, poor self-rated health status, and frequency of daily smoking and drinking.

\section{Statistical analysis}

For the descriptive analysis, unweighted frequencies and weighted proportions of the sample characteristics were calculated. Statistical significance for the bivariate analysis was obtained through the design-based F-test, a corrected weighted version of the Pearson's $\chi^{2}$ test that takes into account complex survey design (30). For the multivariate analysis, independent binomial logistic regression models were built to assess the association between childhood hunger and diabetes, hypertension, rheumatism and osteoporosis while controlling for sociodemographic and health covariates. No multivariate model was run for heart disease due to its low prevalence (only $1.05 \%$ of the sample who experienced hunger had heart disease). Model specification was determined using backward 
and forward stepwise variable selection and based on assessment of goodness-of-fit. Adjusted odds ratios for childhood hunger (reference category: no) were obtained controlling for sociodemographic and health variables. The statistical significance of the association between childhood hunger and outcomes of interest was obtained through the adjusted version of the Wald test, necessary for complex survey data (30). Using the multivariate logistic regression models, predicted probabilities were obtained for the outcomes in which childhood hunger was a statistically significant regressor, i.e., diabetes and osteoporosis. All analyses were carried out in Stata 15 (Stata Statistical Software: Release 15. College Station, TX: StataCorp LLC) using the 'svy' command to account for the complex survey design, and data visualization was carried out in R using ggplot2.

The ELSI-Brazil study was approved by the Research Ethics Committee of the Oswaldo Cruz Foundation, Minas Gerais (CAAE 34649814.3.0000.5091). Genotyping of the cohort population was approved by Brazil's national research ethics committee (CAAE: 63725117.9.0000.5091). Participants signed separate informed consent forms for the interviews, physical measurements, and the laboratory assays, authorized sample storages, and access to administrative records (29).

\section{RESULTS}

Out of the total sample, $24.7 \%$ of older adults experienced hunger during childhood. Table 1 shows that the percentage of older adults who experienced hunger in childhood decreases as age increases. While almost $30 \%$ of adults in the $50-59$-year category experienced hunger during childhood, this percentage was $16 \%$ among adults older than 80 years of age. Older adults of white race $(17.8 \%)$ report significantly less hunger experiences than those of black $(33.0 \%)$, or brown race $(28.6 \%)$. The percentage of adults with more than nine years of education who experienced childhood hunger $(17.3 \%)$ was almost half than those with less than five years of education (33.5\%). For income, the gradient of childhood hunger goes from $7.8 \%$ among those whose household family income is nine or more minimum wages to $33.5 \%$ among those earn less than two times the minimum wage. $33.9 \%$ of adults with jobs that demand intense physical effort reported hunger experiences during childhood, while this percentage was $15.57 \%$ for adults with more sedentary jobs. There is also an important regional disparity; while the percentage of adults with childhood hunger was almost $40 \%$ in the North, it was less than $20 \%$ in the South. A higher percentage of adults with poor self-rated health reported hunger experiences than those with better health. In terms of health behavior, having experienced hunger in childhood was found to be significantly more common among those who smoke on a daily basis but significantly less common among those who drink regularly. Comparing individuals with and without the studied diseases, statistically significant difference in the proportion of childhood hunger is only observed for rheumatism and osteoporosis, but not for hypertension, diabetes or heart disease (Table 2).

Results from the multivariate regression analysis indicate that the association between childhood hunger was statistically significant for diabetes and osteoporosis, but not for hypertension and rheumatism. After adjusting for relevant covariates, we found that older adults who reported having experienced
TABLE 1. Sociodemographic and health characteristics of the sample stratified by childhood hunger experience among older adults, unweighted frequencies and weighted percentages, ELSI-Brazil 2016

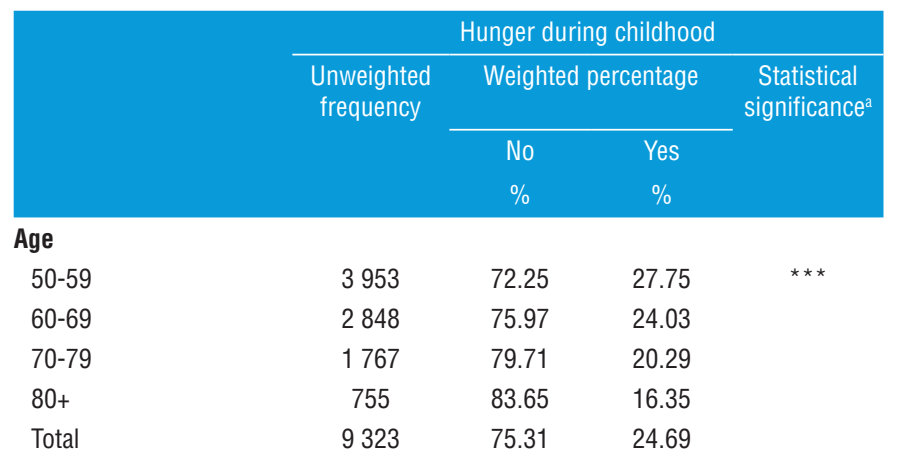

\section{Sex}

Female

Male

5268

4055

75.47

75.13

24.53

Total

9323

White

Black

3556

Brown

878

4242

Others

Total

306

8982

75.31

24.87

24.69

Educational attainment

\section{Less than 5}

Between 5 and 8

9 or more

Total

\section{Household income}

Less than 2 minimum wages

2-5 minimum wages

5-9 minimum wages

$9+$ minimum wages

Total

\section{Occupational status}

Intense physical effort

Some physical effort

Standing or walking

most of the time

Seated most of the time

Total

\section{Region}

North

Northeast

Southeast

South

Midwest

Total

3416

2822

3026

9264

82.17

67.01

71.36

17.83

32.99

66.12

28.64

33.88

$75.40 \quad 24.60$

\section{Residence in urban area}

No

3112

66.51

76.03

33.49

82.70

23.97

$75.30-24.70$

Yes

4258

1141

544

9055

66.55

33.45

75.49

82.98

92.19

75.02

33.45

24.51

17.02

7.81

24.98

1819

66.10

33.90

2943

71.73

28.27

2933

79.09

20.91

1407

84.43

15.57

9102

75.07

24.93

62.99

37.01

67.51

78.14

32.49

2511

3893

21.86

$82.26 \quad 17.74$

$76.27 \quad 23.73$

916

75.31

24.69

Total

1460

72.10

27.90

$75.89 \quad 24.11$

Living with partner

9323

75.31

24.69

No partner

3927

75.88

24.12

(continued) 
TABLE 1. (Continued)

\begin{tabular}{|c|c|c|c|c|}
\hline & \multicolumn{4}{|c|}{ Hunger during childhood } \\
\hline & \multirow{3}{*}{$\begin{array}{l}\text { Unweighted } \\
\text { frequency }\end{array}$} & \multicolumn{2}{|c|}{ Weighted percentage } & \multirow{3}{*}{$\begin{array}{c}\text { Statistical } \\
\text { significance }\end{array}$} \\
\hline & & No & Yes & \\
\hline & & $\%$ & $\%$ & \\
\hline Living with partner & 5396 & 74.99 & 25.01 & \\
\hline Total & 9323 & 75.31 & 24.69 & \\
\hline \multicolumn{5}{|l|}{ Poor self-rated health } \\
\hline No & 3944 & 80.95 & 19.05 & $* * *$ \\
\hline Yes & 5357 & 70.94 & 29.06 & \\
\hline Total & 9301 & 75.33 & 24.67 & \\
\hline \multicolumn{5}{|l|}{ Daily smoking } \\
\hline No & 4733 & 78.25 & 21.75 & $\star \star \star \star$ \\
\hline Yes & 4587 & 72.29 & 27.71 & \\
\hline Total & 9320 & 75.33 & 24.67 & \\
\hline \multicolumn{5}{|l|}{ Drink } \\
\hline Never & 6836 & 73.78 & 26.22 & $\star \star * *$ \\
\hline Eventually & 540 & 76.88 & 23.12 & \\
\hline Regularly & 1940 & 79.84 & 20.16 & \\
\hline Total & 9316 & 75.37 & 24.63 & \\
\hline \multicolumn{5}{|l|}{ Body Mass Index } \\
\hline Normal & 2774 & 74.67 & 25.33 & \\
\hline Overweight & 3536 & 75.79 & 24.21 & \\
\hline Obese & 3013 & 75.34 & 24.66 & \\
\hline Total & 9323 & 75.31 & 24.69 & \\
\hline
\end{tabular}

Source: Prepared by authors using ELSI-Brazil 2016.
Note: Data weighted to account for complex survey design.

a Statistical significance was assessed with a design-based F test, ${ }^{*} p$-value $<0.05$; ${ }^{* *} p$-value $<0.01$;
** $p$-value $<0.001$

hunger during childhood had 20\% higher odds of developing diabetes in adulthood and 38\% higher odds of developing osteoporosis than adults who did not have a hunger experience as a child. As expected, the odds of developing chronic conditions increase as age does. The exception was rheumatism, for which only the 70-79 years old group had a statistically significant odds ratio $(\mathrm{aOR}=2.53 ; 95 \% \mathrm{CI} 1.15,5.6)$ in comparison to the reference group (50-59 years old). Regarding sex, a statistically significant association was found for hypertension and osteoporosis. Being male was associated with a $15 \%$ reduction in the odds of developing hypertension $(\mathrm{aOR}=0.85 ; 95 \% \mathrm{CI}: 0.77$, 0.95 ) and $79 \%$ reduction in the odds of having osteoporosis (aOR $=0.21,95 \% \mathrm{CI}: 0.16,0.28)$. The association with race was only statistically significant for hypertension. In comparison to white people, individuals self-declared as black had $54 \%$ higher odds $(\mathrm{aOR}=1.52 ; 95 \% \mathrm{CI}: 1.25,1.91)$ of having hypertension and individuals self-declared as brown have $17 \%$ higher odds (aOR=1.17; 95\% CI: 1.02, 1.35 respectively). The few statistically significant odds ratios observed for educational attainment in our model did not produce a clear message on the relationship between this covariate and the studied diseases. The association between occupational status and chronic conditions was mostly observed in osteoporosis, where the level of physical effort demanded by the job was inversely associated with the development of this condition. i.e., individuals with jobs that require standing or being seated, are less likely to develop this condition than those with occupations of intense physical effort. Regional variation was only statistically significant for
TABLE 2. Prevalence of hypertension, diabetes, heart disease, arthritis and osteoporosis stratified by childhood hunger experience among older adults, unweighted frequencies and weighted percentages, ELSI-Brazil 2016

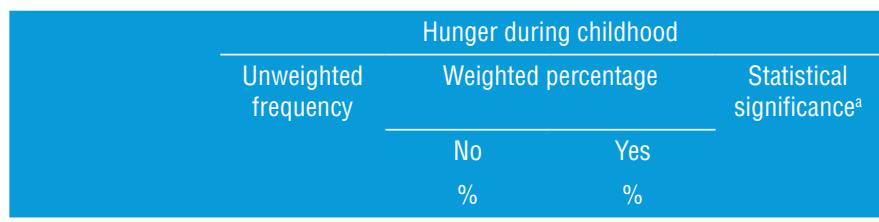

\section{Hypertension}

$\begin{array}{llll}\text { No } & 4341 & 76.41 & 23.59 \\ \text { Yes } & 4961 & 74.31 & 25.69 \\ \text { Total } & 9302 & 75.31 & 24.69\end{array}$

\section{Diabetes}

$\begin{array}{llll}\text { No } & 7762 & 75.78 & 24.22\end{array}$

$\begin{array}{llll}\text { Yes } & 1512 & 73.15 & 26.85\end{array}$

$\begin{array}{llll}\text { Total } & 9274 & 75.37 & 24.63\end{array}$

Any heart disease

$\begin{array}{lccc}\text { No } & 9232 & 75.36 & 24.64 \\ \text { Yes } & 90 & 69.21 & 30.79 \\ \text { Total } & 9322 & 75.31 & 24.69\end{array}$

Arthritis or rheumatism

\begin{tabular}{lllll} 
No & 7238 & 76.25 & 23.75 & $* * *$ \\
Yes & 2016 & 71.73 & 28.27 & \\
Total & 9254 & 75.30 & 24.70 & \\
Osteoporosis & & & & \\
No & 7685 & 76.14 & 23.86 & $* * *$ \\
Yes & 1551 & 71.41 & 28.59 & \\
Total & 9236 & 75.40 & 24.60 & \\
\hline
\end{tabular}

Source: Prepared by authors using ELSI-Brazil 2016.

Note: Data weighted to account for complex survey design. Note: Data weighted to account for complex survey design.
a Statistical significance was assessed with a design-based F test, ${ }^{*} p$-value $<0.05$; ${ }^{* *}$ p-value $<0.01$;

hypertension, while residing in an urban area was positively associated with the presence of diabetes and osteoporosis. Regarding health behaviors, our results found daily smoking to be positively and statistically significantly associated to hypertension (reference category: never smoked; aOR $=1.36$; 95\% CI: $1.15,1.61)$ and osteoporosis $(\mathrm{aOR}=1.13 ; 95 \% \mathrm{CI}: 1.00,1.28)$. For drinking habits, no significant difference was observed between those who do not drink at all and those who drink occasionally, but statistically significant associations were found with hypertension, diabetes and osteoporosis which indicate that regular drinking may be a protective factor for these diseases. Overweight and obesity was positively and significantly associated to the presence of hypertension (reference category: normal weight; $\mathrm{aOR}=1.58 ; 95 \% \mathrm{CI}: 1.40,1.79$ and $\mathrm{aOR}=2.74 ; 95 \% \mathrm{CI}$ : $2.40,3.13$, respectively) and diabetes $(\mathrm{aOR}=1.79 ; 95 \% \mathrm{CI} 1.50$, 2.14 and $\mathrm{aOR}=2.04 ; 95 \% \mathrm{CI}: 1.66,2.51$ ) (Table 3).

Panel A of Figure 1 shows the predicted probability for having diabetes, by childhood hunger, sex and body mass index (BMI). This probability increases as BMI does and is greater for those who experienced hunger in childhood. While among females the impact of childhood hunger grows as BMI increases, among males this is more prominent among individuals with overweight but less among those who are obese. Panel B presents the predicted probability for having osteoporosis and reveals a few things: first, it shows that probability of having osteoporosis 
TABLE 3. Adjusted Odds Ratios (aOR) and 95\% confidence intervals (Cl) from logistic regressions of hypertension, diabetes, rheumatism and osteoporosis, ELSI-Brazil 2016

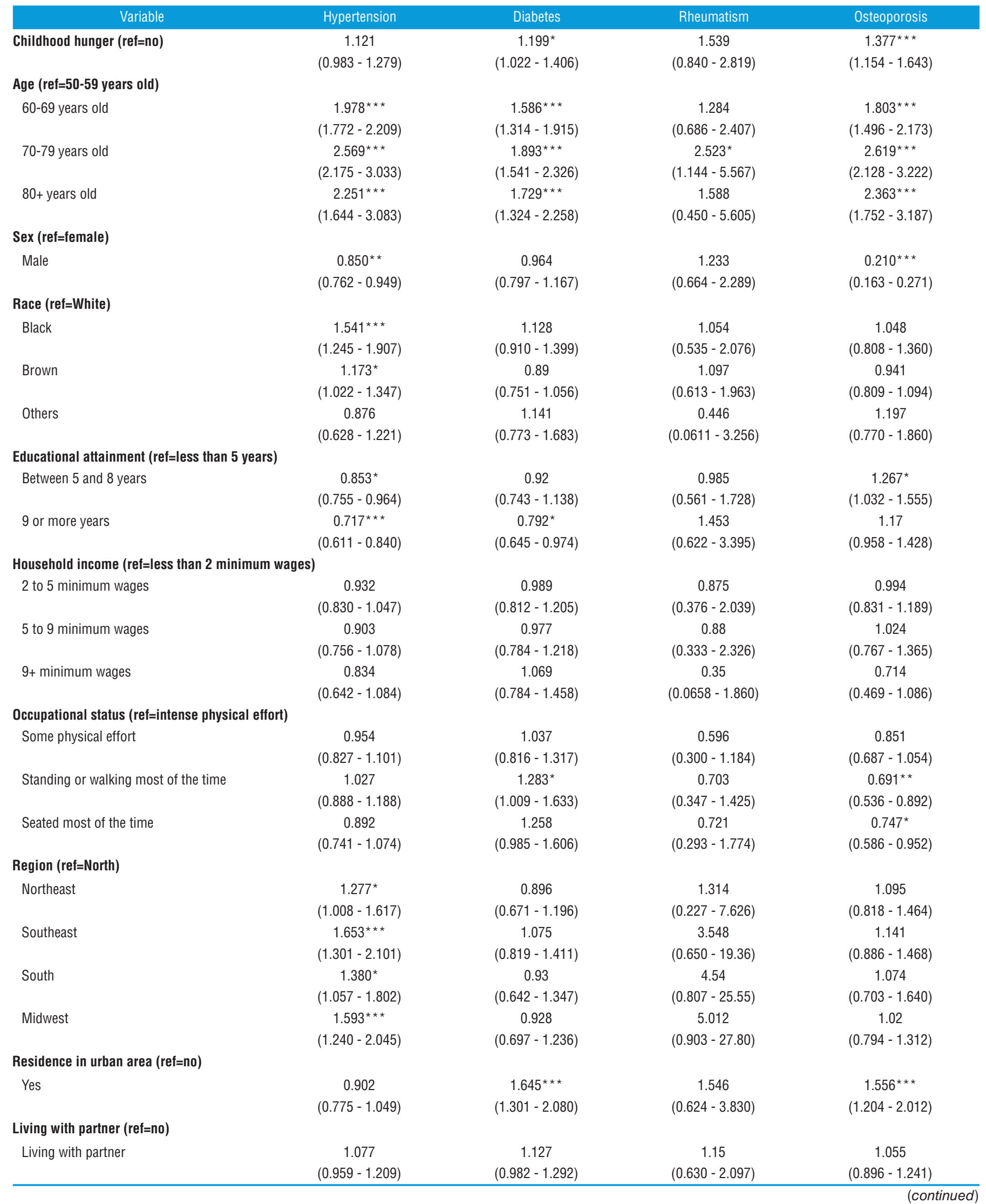


TABLE 3. (Continued)

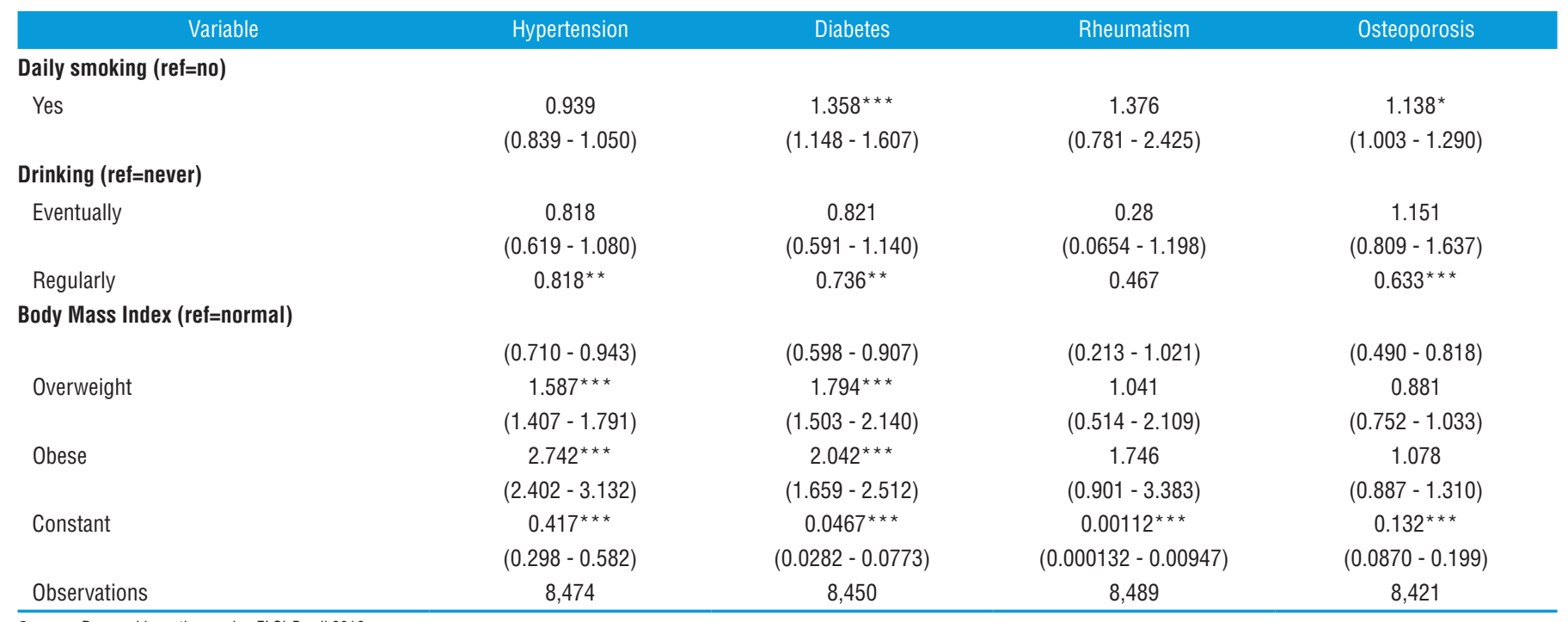

Source: Prepared by authors using ELSI-Brazil 2016.

Note: Data weighted to account for complex survey design.
Statistical significance: ${ }^{*} p$-value $<0.05 ;{ }^{* *} p$-value $<0.01 ;{ }^{* * *} p$-value $<0.001$

is four to five times higher for women than men, as expected; second, it shows that there is no clear gradient of BMI, i.e., having higher BMI does not increase the predicted probability of having osteoporosis; third, it shows that the disparity in the predicted probability of having osteoporosis between those who experienced hunger and those who did not is much greater among women than among men.

\section{DISCUSSION}

Our study showed that one fourth of the Brazilian population aged 50 and over experienced hunger in childhood. This prevalence rate was found to be higher among the younger individuals of this group. It also showed that there is a consistent bivariate association between reporting this harmful exposure in childhood and several variables that describe socioeconomic status, like educational attainment, household income and occupational status. A robust gradient of childhood hunger is observed in regard to educational attainment and household income, meaning that the higher the socioeconomic status the lower is the percentage of individuals who experienced hunger in childhood. Substantial regional disparities were found as well; individuals in the North and Northeast regions were found to be the most affected by hunger during childhood. In addressing our main research question about the impact of childhood hunger on later life health through the multivariate analysis, we found that those who experienced this childhood adverse event have significantly higher odds of having diabetes and osteoporosis, but not the other diseases studied, namely hypertension and rheumatism.

There is a secondary finding that deserves a more detailed discussion. We found that the percentage of individuals who experienced hunger in childhood is higher in the younger cohorts within the studied group. In other words, it indicates that hunger is more common among those whose childhood spanned from late 1960s to late 1970s than among those whose childhood spanned from late 1950s to late 1960s. This gradient is observed for the entire sample, which is representative of the Brazilian population. It is possible that this is simply due to survivor bias, as the oldest people who had these problems as children may not have lived very long and are not included in the survey. Still, it is an important finding that deserves further exploration.

Brazil has a long-standing tradition of placing hunger in the public agenda. Since the work of Josue de Castro in 1946, continuous denunciations against undernourishment set the stage to Fome Zero, an exemplar hunger eradication endeavor that comprised a multisectoral strategy which included an agrarian reform, food banks, school meals and subsidies, among others (31). Between 1992 and 2012, poverty fell from 31.46\% to 8.54\% and extreme poverty from $13.66 \%$ to $3.55 \%$ of the Brazilian population (32). By 2015, the proportion of the population suffering undernourishment was below 5\% (33). However, hunger in childhood was much more prevalent among individuals born before 1990 in Brazil.

The national prevalence of wasting and stunting among children under 5 years of age significantly decreased from $7.1 \%$ to $1.8 \%$ and $19.6 \%$ to $6.8 \%$, respectively between 1989 to 2006 (34), indicating that younger cohorts benefited from Fome Zero. The research community must continue to take advantage of the available data to have a better understanding of the mechanisms underlying the link between childhood adversity and adult health outcomes. In this sense, a life-course approach may contribute to the understanding of health conditions.

Regarding policy implications, our paper has a clear and vital message. Contributing to the increasing literature that reveals how different aspects of childhood disadvantage impact health later in life, we found that childhood hunger is associated with diabetes and osteoporosis among older adults. This draws our attention to the fact that an adverse event that is still affecting millions of children in the world 
FIGURE 1. Predicted probability of diabetes and osteoporosis by childhood experience, sex and BMI among older adults in Brazil, ELSI-Brazil 2016

$$
\text { Hunger in childhood } \rightarrow \text { No } \rightarrow \text { Yes }
$$

\section{Diabetes}
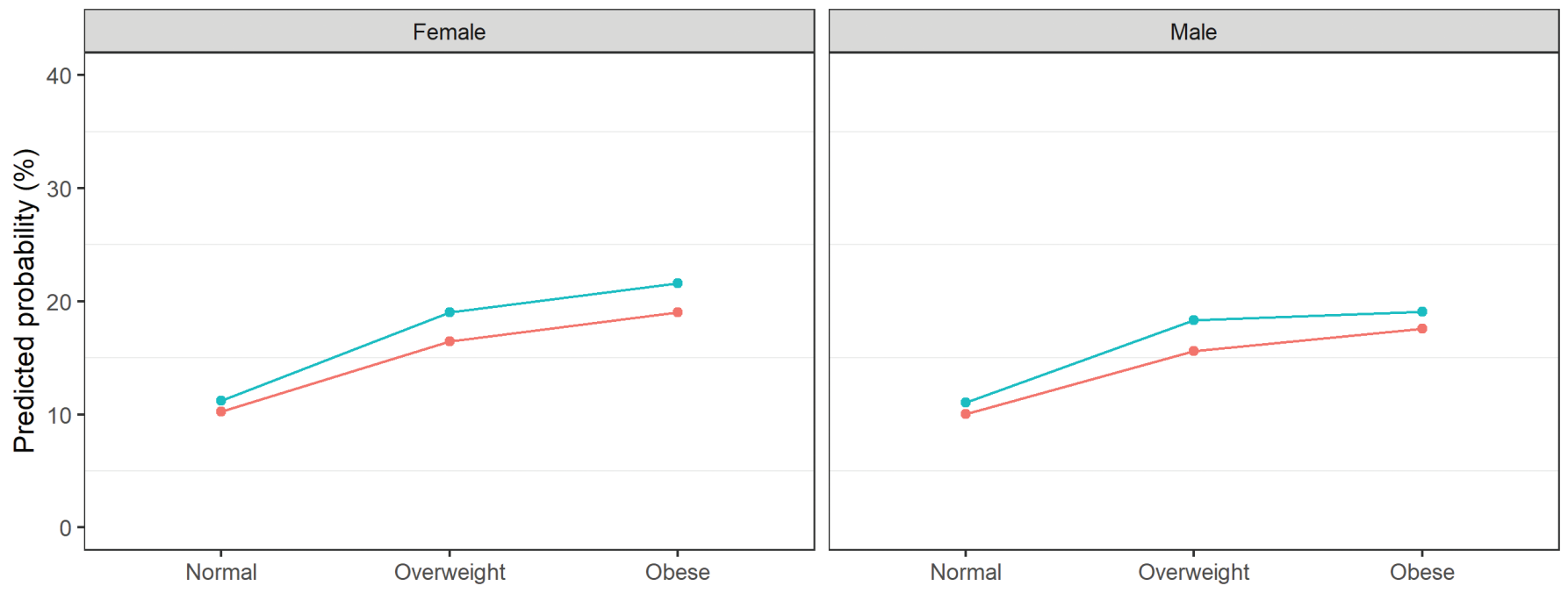

Osteoporosis

Body mass index

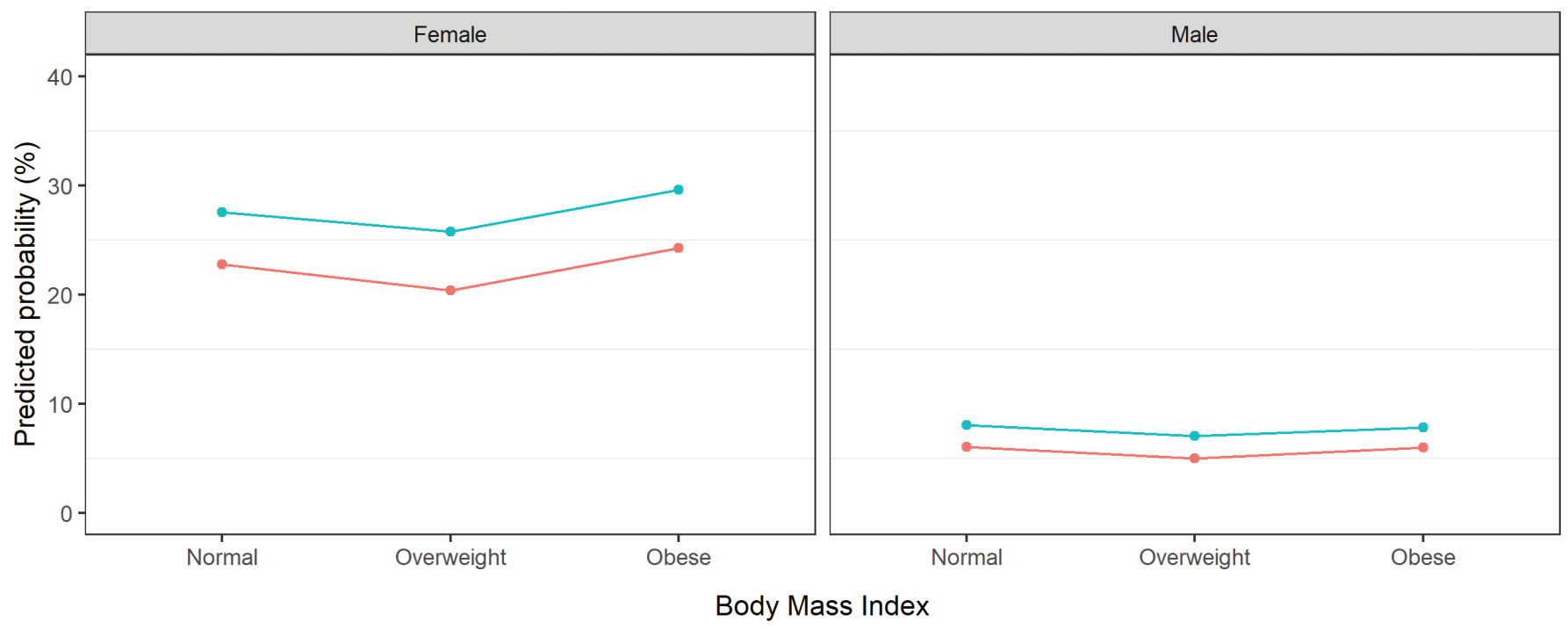

Source: Prepared by authors using ELSI-Brazil 2016

will likely affect them for their entire lives. This contributes to the growing body of evidence that supports that investing in early childhood is a cost-effective way to reduce the burden of disease (35).

This study has several strengths that deserve mentioning. First, to our knowledge, it is the first study to assess the relationship between childhood hunger and later life health with nationally representative data of older adults in Brazil. Second, given that the exposure happened necessarily before the outcome of interest, reverse causality is not a threat for internal validity here. Third, findings from the multivariate regression were presented not only in terms of individual prevalence ratios (allowing us to verify the hypothesized association and also detect specific factors associated with the outcomes) but were also presented in terms of average marginal effects based on predicted probabilities, revealing a more granular view of the relationship between multiple independent variables and the dependent variable. 
Conversely, the work has some limitations. First, it employs an imperfect identification strategy (selection on observables) within a cross-sectional design and, therefore, unobserved confounding cannot be completely ruled out. Second, as data come from a survey, there is always a possibility of recall bias. Third, the exposure variable was constructed from of a broad survey question that does not allow us to identify when deprivation actually occurred in childhood and evidence has found that the effect is more acute when the experience was before age 3 (6). Finally, self-reported measures for the outcomes could threaten the validity of our findings, but this could be improved by using bone mineral density (20), glucose for diabetes, and other measures such as arm length or knee height for overweight and obesity (13) instead of BMI.

\section{Conclusions}

Socioeconomic disadvantage in childhood is a phenomenon that affects individuals beyond their immediate health status. A growing literature has indicated that a variety of disadvantage aspects has far-reaching and long-term effects on the health of individuals throughout the life course. Our study showed an association between childhood hunger and two chronic diseases in later life: diabetes and osteoporosis. For policy -and decision-makers-, our work reaffirms that investing in childhood conditions is as a very cost-effective way to have a healthy society. For the research community, it provides further evidence on which relationships deserve further investigation that can elucidate the underlying mechanisms between childhood adversity and later health outcomes.

Author contributions. LFB and BS conceived the original idea. BS analyzed the data. LFB and BS interpreted the results, wrote and reviewed the paper. All authors reviewed and approved the final version.

\section{Conflicts of interests. None declared.}

Disclaimer. Authors hold sole responsibility for the views expressed in the manuscript, which may not necessarily reflect the opinion or policy of the RPSP/PAJPH and/or PAHO.

\section{REFERENCES}

1. Wiss DA, Brewerton TD. Adverse Childhood Experiences and Adult Obesity: A Systematic Review of Plausible Mechanisms and Meta-Analysis of Cross-Sectional Studies. Physiol Behav. 2020;223:112964.

2. Dong M, Giles Wayne H, Felitti Vincent J, Dube Shanta R, Williams Janice E, Chapman Daniel P, et al. Insights Into Causal Pathways for Ischemic Heart Disease. Circulation. 2004;110(13):1761-6.

3. Huang C, Soldo BJ, Elo IT. Do early-life conditions predict functional health status in adulthood? The case of Mexico. Soc Sci Med. 2011;72(1):100-7.

4. Peele M. Childhood Conditions Predict Chronic Diseases and Functional Limitations Among Older Adults: The Case of Indonesia. J Aging Health. 2019;31:1892-916.

5. Hughes K, Bellis MA, Hardcastle KA, Sethi D, Butchart A, Mikton $\mathrm{C}$, et al. The effect of multiple adverse childhood experiences on health: a systematic review and meta-analysis. Lancet Public Health. 2017;2(8):e356-e66.

6. Abeliansky AL, Strulik H. Hungry children age faster. Econ Hum Biol. 2018;29:211-20.

7. Bertoni M. Hungry today, unhappy tomorrow? Childhood hunger and subjective wellbeing later in life. J Health Econ. 2015;40:40-53.

8. Stickley A, Leinslau M. Childhood hunger and depressive symptoms in adulthood: Findings from a population-based study. J Affect Disord. 2018;226:332-8.

9. Verropoulou G, Zakynthinou M. Contrasting concurrent and childhood socioeconomic predictors of self-rated health among older European men and women. J Biosoc Sci. 2017;49:478-97.

10. Fransen HP, Peeters PH, Beulens JW, Boer JM, de Wit GA, OnlandMoret NC, et al. Exposure to Famine at a Young Age and Unhealthy Lifestyle Behavior Later in Life. PLoS One. 2016;11(5):e0156609.

11. Nicholson A, M B, M M, R R, Marmot M. Socio-economic influences on self-rated health in Russian men and women--a life course approach. Soc Sci Med. 2005;61(11):2345-54

12. Maharani AA-O. Childhood Socioeconomic Status and Cognitive Function Later in Life: Evidence From a National Survey in Indonesia. J Geriatr Psychiatry Neurol 2020;33:214-22.

13. Zhang Z, D. G, Hayward MD. Childhood nutritional deprivation and cognitive impairment among older Chinese people. Soc Sci Med 2010;71:941-9.

14. Peele M. Domains of Childhood Disadvantage and Functional Limitation Trajectories Among Midlife Men and Women in China. J Aging Health. 2020;32:501-12.
15. Cui HX, Smith JP, Zhao YH. Early-life deprivation and health outcomes in adulthood: Evidence from childhood hunger episodes of middle-aged and elderly Chinese. J Dev Econ. 2020;143:13.

16. Sawaya AL, Roberts S. Stunting and future risk of obesity: principal physiological mechanisms. Cad Saude Publica. 2003;19:S21-S8.

17. Danese A, McEwen BS. Adverse childhood experiences, allostasis, allostatic load, and age-related disease. Physiol Behav. 2012;106(1):29-39.

18. Victora CG, Adair L, Fall C, Hallal PC, Martorell R, Richter L, et al. Maternal and child undernutrition: consequences for adult health and human capital. Lancet. 2008;371:340-57.

19. Kueper J, Beyth S, Liebergall M, Kaplan L, Schroeder JE. Evidence for the Adverse Effect of Starvation on Bone Quality: A Review of the Literature. Int J Endocrinol. 2015;2015:628740.

20. Zong L, Cai L, Liang J, Lin W, Yao J, Huang H, et al. Exposure to famine in early life and the risk of osteoporosis in adulthood: a prospective study. Endocr Pract. 2019;25:299-305.

21. Cooper C, Javaid MK, Taylor P, Walker-Bone K, Dennison E, Arden $\mathrm{N}$. The fetal origins of osteoporotic fracture. Calcif Tissue Int. 2002;70(5):391.

22. Cândido FG, Bressan J. Vitamin D: link between osteoporosis, obesity, and diabetes? Int J Mol Sci. 2014;15:6569-91.

23. McGrath J. Does 'imprinting' with low prenatal vitamin D contribute to the risk of various adult disorders? Med Hypotheses. 2001;56(3):367-71

24. Sawaya AL, Martins P, Hoffman D, Roberts SB. The Link between Childhood Undernutrition and Risk of Chronic Diseases in Adulthood: a Case Study of Brazil. Nutr Rev. 2003;61(5):168-75.

25. Hoffman DJ, Sawaya AL, Verreschi I, Tucker KL, Roberts SB. Why are nutritionally stunted children at increased risk of obesity? Studies of metabolic rate and fat oxidation in shantytown children from Sao Paulo, Brazil. Am J Clin Nutr. 2000;72(3):702-7.

26. Zunzunegui M-V, Alvarado B-E, Béland F, Vissandjee B. Explaining health differences between men and women in later life: A crosscity comparison in Latin America and the Caribbean. Soc Sci Med. 2009;68(2):235-42.

27. Alvarado BE, Zunzunegui M., Béland F, Bamvita JM. Life course social and health conditions linked to frailty in Latin American older men and women. J Gerontol A Biol Sci Med Sci. 2008;63:1399-406.

28. Alvarado BE, Ro G, Zunzunegui MV. Gender differences in lower extremity function in Latin American elders: seeking explanations from a life-course perspective. J Aging Health. 2007;19:1004-24. 
29. Lima-Costa MF, de Andrade FB, Souza PRBd, Neri AL, Duarte YAdO, Castro-Costa E, et al. The Brazilian Longitudinal Study of Aging (ELSI-Brazil): Objectives and Design. Am J Epidemiol. 2018;187(7):1345-53.

30. Heeringa S, West BT, Berglund PA. Applied survey data analysis. Chapman and Hall; 2017.

31. da Silva JG. From Fome Zero to Zero Hunger: a global perspective. FAO; 2019.

32. Câmara Interministerial de Segurança Alimentar e N. Balanço das ações do Plano Nacional de Segurança Alimentar e Nutricional-PLANSAN 2012-2015. Ministério do Desenvolvimento Social e Combate à Fome. Brasília; 2014.

33. United Nations-FAO. FAO Hunger Map: Millenium Development Goal 1 and the World Food Summit Hunger Targets 2015.
34. Aplicada IdPE. Objetivos de Desenvolvimento do Milênio. Relatório nacional de acompanhamento. Brasília: Ipea; 2014.

35. Bhutta ZA, Das JK, Rizvi A, Gaffey MF, Walker N, Horton S, et al. Evidence-based interventions for improvement of maternal and child nutrition: what can be done and at what cost? Lancet. 2013;382(9890):452-77.

Manuscript received on 29 August 2020; revised version accepted for publication on 1 January 2021.

\section{Experiencias de hambre en la niñez y enfermedades crónicas en etapas posteriores de la vida en adultos mayores de Brasil}

RESUMEN Objetivos. Evaluar la asociación entre las experiencias de hambre en la niñez y la prevalencia de enfermedades crónicas en las etapas posteriores de la vida.

Métodos. Se realizó un estudio transversal utilizando como línea de base los datos del Estudio Longitudinal del Envejecimiento en Brasil (ELSI-Brasil), un estudio nacional representativo de personas de 50 años o más $(n=9412)$. Se emplearon análisis univariado y bivariado para describir la muestra, y regresión logística multivariada para examinar la asociación entre el hambre en la niñez y la hipertensión, la diabetes, la artritis y la osteoporosis. Se calcularon las razones de posibilidades ajustadas y las probabilidades previstas.

Resultados. El 24,7\% de los brasileños de 50 años o más pasó hambre en la niñez. Esta experiencia perjudicial fue considerablemente más común en las personas no blancas, las personas con menor nivel de instrucción, las personas con ingresos familiares bajos y los trabajadores de mano de obra pesada. También se observó una variación regional, puesto que la prevalencia de individuos que expresaron haber pasado hambre en la niñez fue mayor en las regiones Norte y Nordeste. Luego de controlar las covariables, el análisis multifactorial reveló que los adultos mayores que dijeron haber pasado hambre en la niñez tenían una probabilidad 20\% mayor de tener diabetes en la edad adulta (aOR = 1,20, IC 95\%: 1,02 - 1,41) y $38 \%$ mayor de tener osteoporosis (aOR = 1,38, IC 95\%: 1,15-1,64) que los adultos que no habían pasado hambre en la niñez.

Conclusiones. El estudio reveló una asociación entre el hambre en la niñez y dos enfermedades crónicas en las etapas posteriores de la vida: la diabetes y la osteoporosis. Este trabajo reafirma que invertir en las condiciones de vida de las personas en la niñez es una manera costoeficaz de tener una sociedad saludable, al tiempo que aporta evidencia acerca de relaciones que merecen investigarse más a fin de esclarecer los mecanismos subyacentes.

Palabras clave Hambre; enfermedad crónica; envejecimiento; diabetes mellitus; osteoporosis; Brasil. 


\section{Experiência de passar fome na infância e problemas crônicos de saúde posteriores em idosos no Brasil}

RESUMO Objetivos. Avaliar a associação entre a experiência de passar fome na infância e a prevalência posterior de doenças crônicas.

Métodos. Um estudo transversal foi realizado a partir de dados básicos do Estudo Longitudinal da Saúde dos Idosos Brasileiros (ELSI-Brasil), uma pesquisa com representatividade nacional realizada com pessoas de 50 anos ou mais $(n=9.412$ ). Análises univariadas e bivariadas foram usadas para descrever a amostra e a regressão logística multivariada foi aplicada para examinar a associação entre passar fome na infância e hipertensão, diabetes, artrite e osteoporose. Foram calculadas razões de chances (odds ratio, OR) ajustadas e probabilidades previstas.

Resultados. Verificou-se que $24,7 \%$ dos brasileiros com 50 anos ou mais passaram fome na infância. Esta exposição prejudicial foi significativamente mais frequente em pessoas não brancas, com nível de instrução menor e renda familiar mais baixa e em trabalhadores braçais. Observou-se também uma variação regional, com uma maior prevalência de pessoas que relataram ter passado fome na infância nas Regiões Norte e Nordeste. Na análise multivariada, nos idosos que informaram ter passado fome na infância, a probabilidade foi 20\% maior de ter diabetes na idade adulta (ORaj 1,20; IC 95\% 1,02-1,41) e 38\% maior de ter osteoporose (ORaj 1,38, IC 95\% 1,15-1,64) em comparação aos adultos que não passaram fome na infância, após o controle de covariáveis.

Conclusões. O estudo demonstrou associação entre passar fome na infância e duas doenças crônicas na vida adulta: diabetes e osteoporose. Este trabalho reitera que investir na infância é uma maneira custo-efetiva de se criar uma sociedade saudável e fornece evidências sobre relações que devem ser pesquisadas mais a fundo para esclarecer os processos subjacentes.

Palavras-chave Fome; doença crônica; envelhecimento; diabetes mellitus; osteoporose; Brasil. 